\title{
Performance and Emission Characteristics of CI Engine with Modification in Fuel Injector
}

\author{
Somanath Swamy R H M, Hiregoudar Yerrennagoudar, Mahesh G
}

\begin{abstract}
Work has been carried out using four stroke single cylinder diesel engine with retrofit attached with fuel injector and at optimum injection pressure 210 bar and 230 BTDC. The main purpose of using retrofit is to achieve HCCI (Homogeneous charge compression ignition) with which emissions can be reduced. Four Variants of retrofits were used and with $V$-cut type retrofit it was found that there is reduction in toxic emission like $\mathrm{CO}$ and NO but there was slight increase in HC emission when compared with normal fuel injector. Engine performance was compared with normal injector and injector with $V$-cut and it was found that Break thermal efficiency was increased by $0.25 \%$ at full load and $1.53 \%$ at $80 \%$ load and specific fuel consumption decreased by $0.01 \%$.
\end{abstract}

Keywords: Fuel Injector, HCCI, Retrofit, Emissions.

\section{INTRODUCTION}

The Diesel engine is a very hot cake topic for most of the researchers since from decades. Many experimental works are being carried out to reduce emissions because most of the toxic emissions are released from these engines. Most of the air borne diseases is occurred because of these toxic emissions. In this view many researchers are working towards reducing emissions. In this connection fuel injector plays a vital role since fuel sprayed from fuel injector. Different types of fuel injector are available with different nozzle hole sizes and with varying number of holes. But if the numbers of holes increase it leads to more fuel consumption which will increase specific fuel consumption. The present work has been carried out with four variants of retrofit.
Revised Manuscript Received on February 05, 2020.

* Correspondence Author

Somanath Swamy R H M*, Assistant Professor, Department of Mechanical Engineering, Rao Bahadur Y Mahabaleshwarappa Engineering College, Ballari, Karnataka, India. Email: somswamy@gmail.com.

Dr. Hiregoudar Yerrennagoudar, Professor, Department of Mechanical Engineering, Rao Bahadur Y Mahabaleshwarappa Engineering College, Ballari, Karnataka, India.

Mahesh G, Assistant Professor, Department of Mechanical Engineering, Rao Bahadur Y Mahabaleshwarappa Engineering College, Ballari, Karnataka, India.

(C) The Authors. Published by Blue Eyes Intelligence Engineering and Sciences Publication (BEIESP). This is an open access article under the CC BY-NC-ND license (http://creativecommons.org/licenses/by-nc-nd/4.0/)

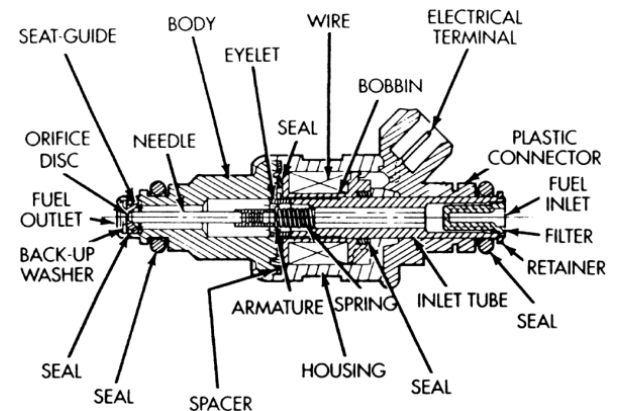

Fig-1: Figure shows parts of fuel injector.

\section{LITERATURE SURVEY}

1.W Ethan Eagle et al. has been experimentally investigated on spray behavior from multi hole nozzle, since spray pattern and spray break up length is important to know for further improvements in engine efficiency and even reducing emissions this investigation was carried by high speed imaging of diesel spray from injector employed in the CRDI system. The fuel injector nozzle had 4 holes aligned on a radial plane with diameters of 90, 110, 130 and $150 \mathrm{~lm}$. Fuel was injected at room temperature at chamber densities of 17.5, 24.2, and $32.7 \mathrm{~kg} / \mathrm{cub}-\mathrm{m}$ and FIP was varied from 1000, 1500 and 2000 bar. From the results it was observed that the spray diffusion information showed significant variation in the spray geometry at past times and the greatest penetration distance did not occur along the spray centerline during the transient period of injection.

2. F Ruiz et al. This paper involves the investigation of design and working conditions of the engine on fuel flow and its atomization and even fuel properties were also been investigated. The plain-orifice and swirl atomizers were investigated and compared with each other. It was observed that atomization was obtained but there was more flow rate. Correlations are obtained for discharge coefficient and spray angle for fuel injection as a function of 8 different dimensionless variables. Because of this more flow rate it was recommended to go for improved design of fuel injectors.

3. M E McCracken et al. This paper is basically focused on the swirl motion of fuel being injected which is quite important parameter too since it effects mixing of fuel jets, heat release, emissions and overall engine performance 
which can be effected by the swirling action / swirl flow field so in this paper it is been investigated that how these parameters effect by varying levels of swirl flow fields most favorable level of swirl for each geometry that results from a balance between increased jet surface area \& hence, mixing rates \& utilization of air in the chamber. The split injections may have a greater role in determining the mixing properties than spray-spring interactions as regards the fraction of the fuel injected in the multiple events and other features of the injection profiles.

4. Nithya Mahottamananda Jayapal et al. This paper is focused on the atomization of the fuel by swirl injectors since swirling motion spreads the fluid due to the effect of the centrifugal force and spread out in the form of a hollow cone liquid sheet as the fluid leaves the exit orifice. Experimental investigation of plug type swirl injector at varying injection pressure resulted in decrease in breakup length, the spray cone angle and increase in volume flow rate, while in turn there is decrease in the discharge co-efficient with low FIP, break up length is less for plug type swirl injector which is important spray characteristic required in combustion chamber of hybrid rocket.

5. Avinash Kumar Agarwal et.al has been conducted experiment focusing on the emission and performance characteristics of single cylinder diesel engine by varying the parameters like injection timing (SOI-start of injection) and injection pressure (FIP-Fuel injection pressure). In observation at lower FIP and advanced spark timings gave good ROHR (rate of heat release) in early combustion stages, BTE (brake thermal efficiency) was also increased with reduction in exhaust gasses. $\mathrm{CO}$ and $\mathrm{HC}$ emissions were reduced however the NOx emissions were increased.

Most of the researchers worked in the field of increasing the number of nozzle holes, varying injection pressure, split injection, pilot injection method. With all these literature survey it is found that with one are the other methods toxic emissions can be reduced like $\mathrm{CO}, \mathrm{HC}$ and NO. But gap is identified from the literature survey that none of the researchers worked in the modification of fuel injector. In this view this paper is made with modification in the fuel injector.

\section{METHODOLOGY}

- Designing various profiles of retrofit using solid edge software.

- Use of D2 alloy steel for manufacturing retrofits.

- Modifying fuel injector in order to fit the retrofits.

- Experiments were conducted with various designed retrofits.

\section{EXPERIMENTAL SETUP}

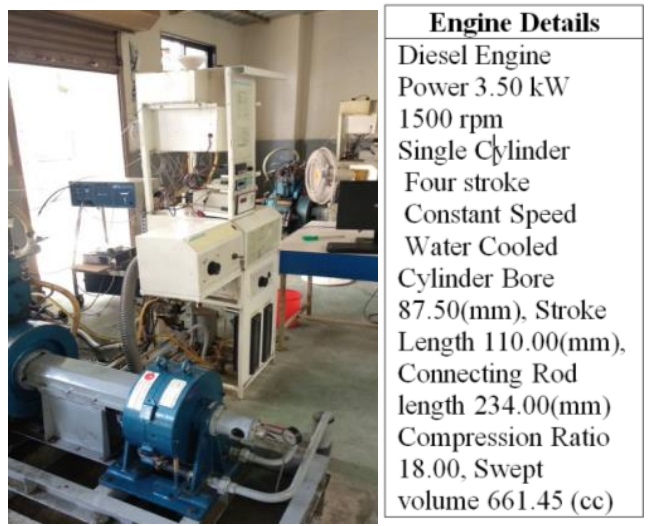

Fig-2: Figure shows four experimental setup

V. FUEL PROPERTIES

\begin{tabular}{|c|c|}
\hline $\begin{array}{c}\text { Density at } \mathbf{2 0}^{\circ} \mathrm{C} \\
(\mathrm{kg} / \mathrm{m} 3)\end{array}$ & 0.829 \\
\hline Boiling point $\left({ }^{\circ} \mathrm{C}\right)$ & 260 \\
\hline Pour point $\left({ }^{\circ} \mathrm{C}\right)$ & -1 \\
\hline Mole weight & 200 \\
\hline $\begin{array}{c}\text { Cetane number } \\
\text { Latent heat of } \\
\text { vaporization }(\mathrm{kJ} / \mathrm{kg})\end{array}$ & 620 \\
\hline $\begin{array}{c}\text { Auto ignition } \\
\text { temperature }\left({ }^{\circ} \mathrm{C}\right)\end{array}$ & 320 \\
\hline $\begin{array}{c}\text { Viscosity at } 30^{\circ} \mathrm{C} \\
\text { (MPa) }\end{array}$ & 3.35 \\
\hline
\end{tabular}

VI. RETROFIT MODELS

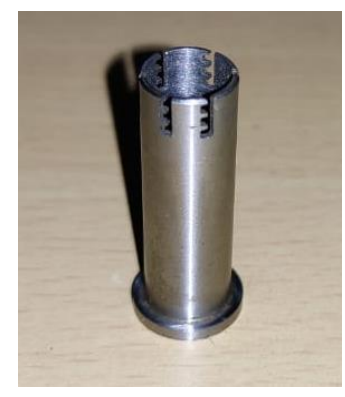

Fig-3: Single side blade cut model

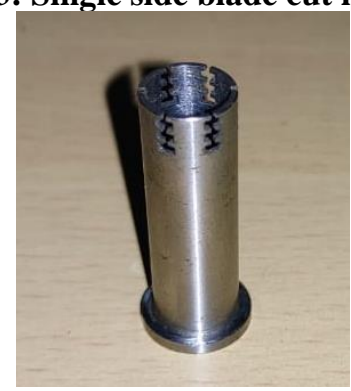

Fig-4: Double side blade cut model 


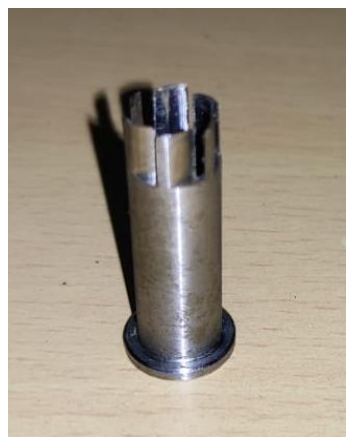

Fig-5: Curved blade cut model

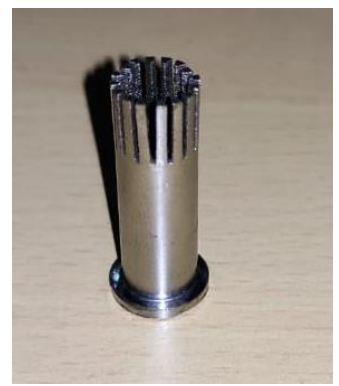

Fig-6: V-cut model

\section{RESULT AND DISCUSSION}
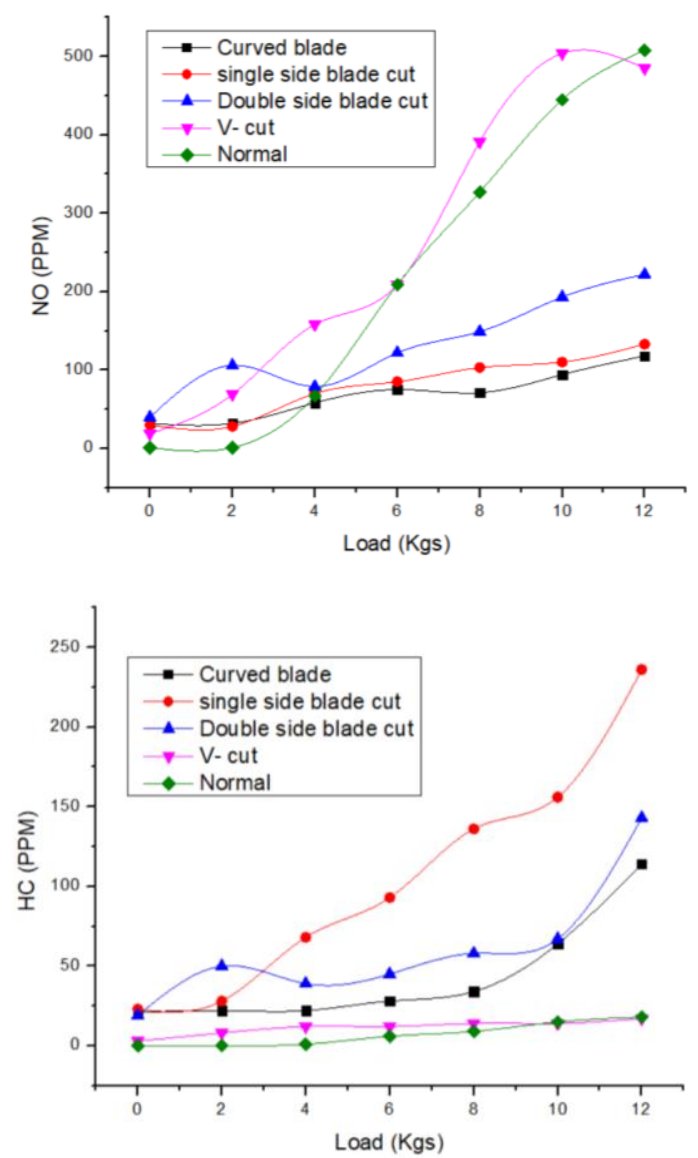

Retrieval Number: C5261029320/2020@BEIESP

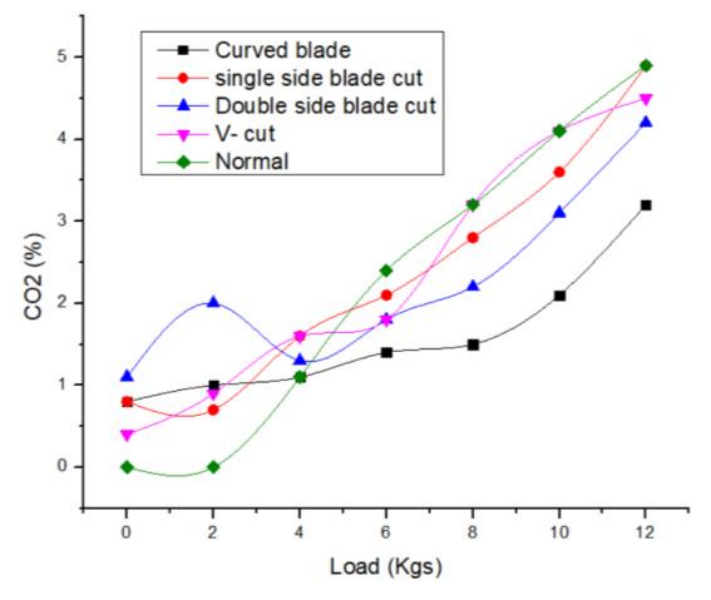

VIII. CONCLUSION

- BTHE increased by $0.25 \%$ at full load and $1.53 \%$ at $80 \%$ load with V-cut retrofit.

- CO emission decreased with V-cut retrofit.

- HC emission decreased with V-cut retrofit.

- NO emission decreased with curved blade retrofit.

- SFC decreased with V-cut retrofit.

- Smoke Opacity decreased with V-cut retrofit.
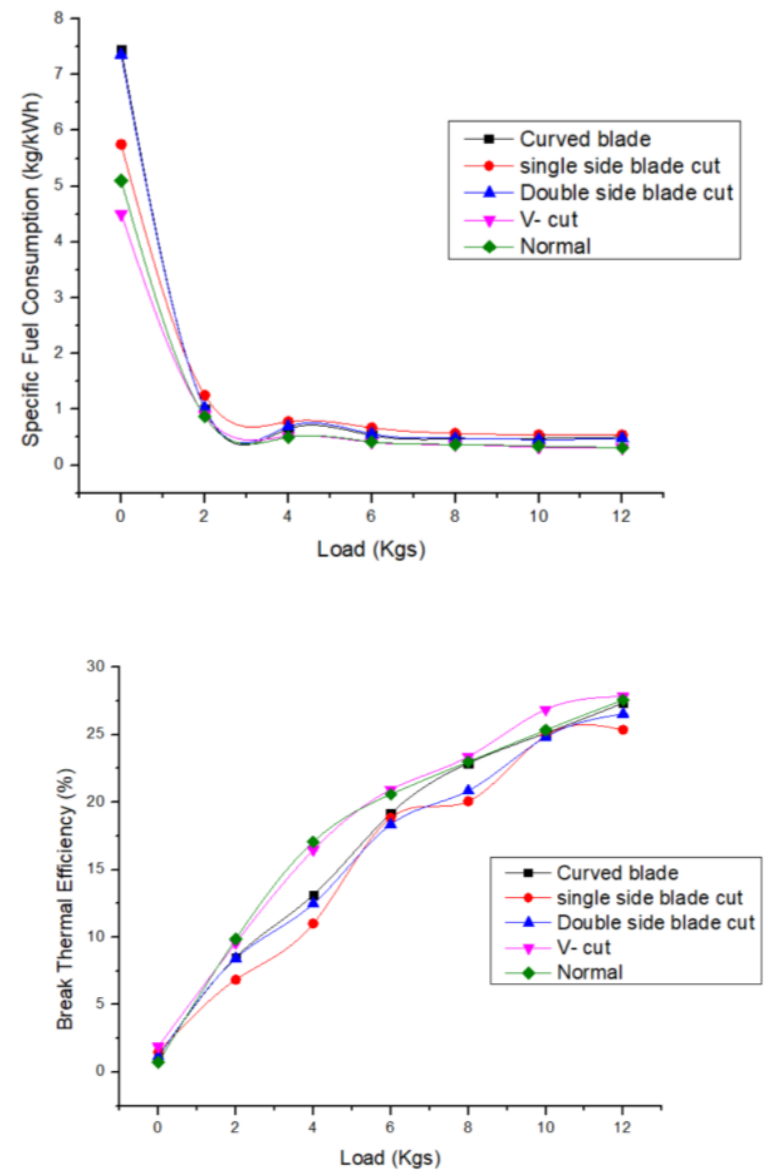

Published By:

Blue Eyes Intelligence Engineering 

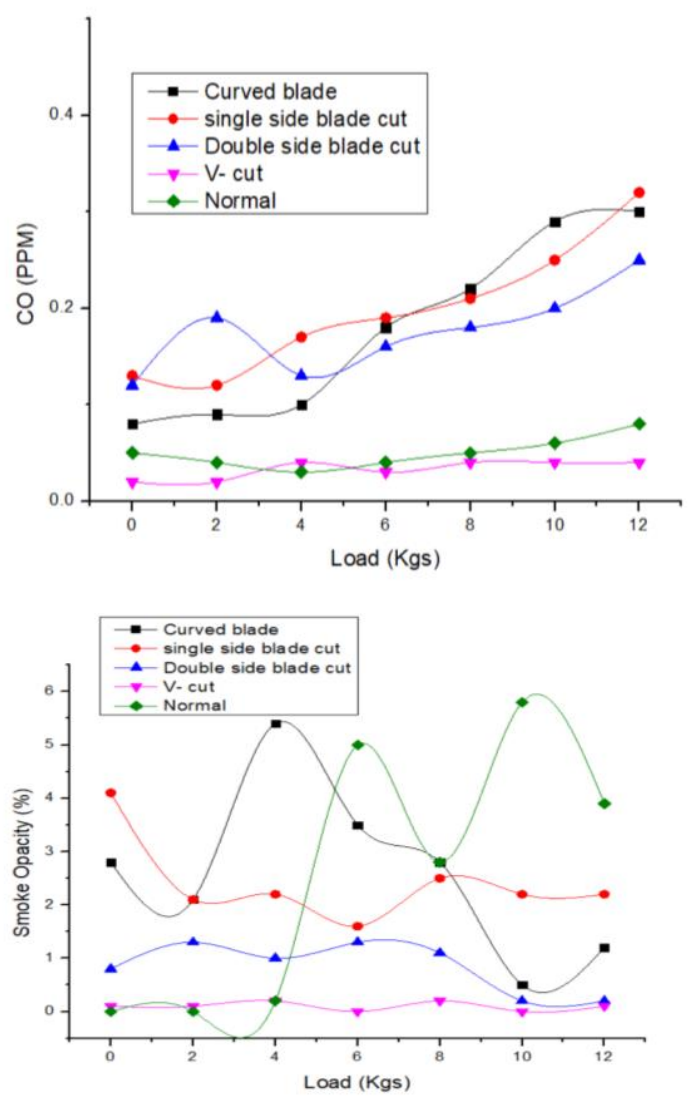

\section{REFERENCES}

1. Agarwal, AK Dhar, A Gupta, JG Kim, WI Choi, K Lee, CS \& Park S(2015). Effect of fuel injection pressure and injection timing of Karanja biodiesel blends on fuel spray, engine performance, emissions and combustion characteristics. Energy Conversion and Management, 91, 302-314. doi:10.1016/j.enconman.2014.12.004.

2. Chen, PC Wang, WC Roberts, WL \& Fang T(2013). Spray and atomization of diesel fuel and its alternatives from a single-hole injector using a common rail fuel injection system. Fuel, 103, 850-861. doi:10.1016/j.fuel.2012.08.013.

3. Eagle, WE Morris, SB \& Wooldridge, MS(2014). High-speed imaging of transient diesel spray behavior during high pressure injection of a multi-hole fuel injector. Fuel, 116, 299-309. doi:10.1016/j.fuel.2013.07.120.

4. Lee, CS Park, SW \& Kwon SI (2005). An Experimental Study on the Atomization and Combustion Characteristics of Biodiesel-Blended Fuels. Energy \& Fuels, 19(5), 2201-2208. doi:10.1021/ef050026h.

5. Lee, CH Lee, KH \& Lim, KB (2010). Effects of injection parameters on the spray characteristics of swirl and slit injectors using the Mie-scattering method. International Journal of Automotive Technology, 11(3), 435-440. doi:10.1007/s12239-010-0053-x.

6. Li L Diver, C Atkinson, J Giedl-Wagner, R \& Helml HJ (2006). Sequential Laser and EDM Micro-drilling for Next Generation Fuel Injection Nozzle Manufacture. CIRP Annals, 55(1), 179-182. doi:10.1016/s0007-8506(07)60393-X.

7. Mccracken ME, \& Abraham J (2001). Swirl-Spray Interactions in a Diesel Engine. SAE Technical Paper Series. doi:10.4271/2001-01-0996.

8. Shiraishi, H Ipri, SL \& Cho, D.-I. D. (1995). CMAC neural network controller for fuel-injection systems. IEEE Transactions on Control Systems Technology, 3(1), 32-38. doi:10.1109/87.370707.

9. Jayapal, SNM Rafnaz M, \& Kadiresh PN. (2018). Spray characteristics of plug type swirl injector. 2018 Advances in Science and Engineering Technology International Conferences (ASET). doi:10.1109/icaset.2018.8376804.

10. Suh, HK, \& Lee, CS. (2008). Effect of cavitation in nozzle orifice on the diesel fuel atomization characteristics. International Journal of Heat and Fluid Flow, 29(4), 1001-1009. doi:10.1016/j.ijheatfluidflow.2008.03.014.

11. Somanath Swamy R H M, "Performance of IC engine with Varying number of nozzle holes and Compression ratio with WCO biodiesel", Journal of Emerging Technologies and Innovative Research Page
566-572, ISSN-2349-5162, UGC Approved (Journal No: 63975), Volume 6, Issue 5, May 2019.

12. Prabhu Kishore, N., Alekhya, N., \& Bridjesh, P. (2017). Experimental Investigation by Varying Fuel Injection Pressure on CI Engine. Materials Today: Proceedings, 4(8), 8394-8399. doi:10.1016/j.matpr.2017.07.183.

\section{AUTHORS PROFILE}

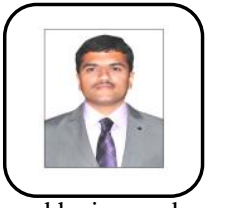

Somanath Swamy R H M, Working as Assistant Professor in the Department of Mechanical Engineering, Rao Bahadur Y Mahabaleshwarappa Engineering College, Ballari, Karnataka has Teaching Experience of 8 years and Research experience of 5 years. Area of Research is IC Engines and Fluid Flow and he is member of MISTE. Email: somswamy@gmail.com

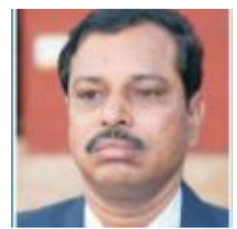

Dr. Hiregoudar Yerrennagoudar, Working as Professor in the Department of Mechanical Engineering, Rao Bahadur Y Mahabaleshwarappa Engineering College, Ballari, Karnataka has pursued his Ph.D from JNTU and has carried out more than 10 research projects sponsored by AICTE-New Delh and KSCST. He has published more than 120 International journals under his name and visited Boston, Yale \& Texas University for invited talks.

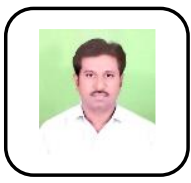

Mahesh G, Working as Assistant Professor in the Department of Mechanical Engineering, Rao Bahadur Y Mahabaleshwarappa Engineering College, Ballari, Karnataka has Teaching Experience of 8 years. Area of Research is IC Engines. He is member of MISTE, SESI 